\title{
ANTARA E-COMMERCE, M-BISNIS \& E-BISNIS DALAM BISNIS ONLINE
}

\author{
Rudi Setiawan \\ 165100105 \\ Fakultas Komputer \\ rudisetiawan.student@umitra.ac.id
}

\begin{abstract}
Bisnis Online merupakan segala jenis kegiatan usaha atau bisnis yang dilakukan secara online / melalui internet. Setiap pelaku usaha yang sebagian aktivitasnya ataupun semua aktivitas bisnisnya dilakukan melalui internet, bisa dikatakan mereka menjalankan bisnis online.
\end{abstract}

E-Commerce atau Electronic Commerce yaitu secara umum dapat diartikan sebagai transaksi jual beli secara elektronik melalui media internet. Selain itu, E-commerce juga dapat diartikan sebagai suatu proses berbisnis dengan memakai teknologi elektronik yang menghubungkan antara perusahaan, konsumen dan masyarakat dalam bentuk transaksi elektronik dan pertukaran atau penjualan barang, servis, dan informasi secara elektronik.

E-bisnis atau Electronic Business dapat diartikan sebagai kegiatan bisnis yang dilakukan secara otomatis dan semiotomatis dengan menggunakan sistem informasi komputer. Istilah yang pertama kali diperkenalkan oleh Lou Gerstner, seorang CEO perusahaan IBM ini, sekarang merupakan bentuk kegiatan bisnis yang dilakukan dengan menggunakan teknologi Internet. E-bisnis memungkinkan suatu perusahaan untuk berhubungan dengan sistem pemrosesan data internal dan eksternal mereka secara lebih efisien dan fleksibel.

Kata Kunci : Bisnis dan Internet. 


\section{A. PENDAhuluan}

Sudah tidak asing lagi bagi kita istilah E-Commerce dan Ebisnis. E-Commerce secara umum dapat diartikan sebagai transaksi jual beli secara elektronik melalui media internet. Selain itu, Ecommerce juga dapat diartikan sebagai suatu proses berbisnis dengan memakai teknologi elektronik yang menghubungkan antara perusahaan, konsumen dan masyarakat dalam bentuk transaksi elektronik dan pertukaran atau penjualan barang, servis, dan informasi secara elektronik. Dalam melakukan E-Commerce penggunaan internet menjadi pilihan favorit oleh kebanyakan orang karena kemudahankemudahan yang dimiliki oleh jaringan internet tersebut. Sedangkan yang dimaksud dengan Electronic Business atau E-Business adalah suatu kegiatan transaksi, jual-beli, bisnis yang dilakukan melalui perangkat elektronik atau dengan internet sehingga perusahaan dapat langsung berinteraksi dengan costumer, supplier maupun rekan bisnis. Atau arti yang lebih singkat dari e-business yaitu penggunaan Teknologi Informasi dan Komunikasi untuk menjalankan sekaligus mengelola bisnisnya sehingga dapat memperoleh keuntungan. Teknologi Informasi dan Komunikasi pada e-business digunakan untuk meningkatkan bisnis perusahaan yang mencangkup semua aspek yang berorientasi pada profit maupun nonprofit suatu perusahaan. E-business dapat dikatakan juga sebagai iklan supaya para konsumen dapat membeli produk-produk perusahaan. Sehingga ebusiness sangat berguna bagi ecomerce, karena fungsi dari ebusiness yaitu untuk mendukung bagian-bagian pada perusahaan seperti bagian prroduksi, finance, marketing dan lain-lain. Jadi perusahaan akan menggunakan Teknologi Informasi dan Komunikasi untuk menjalankan sekaligus mengelola bisnisnya sehingga mendapatkan keuntungan. ECommerce merupakan bagian dari E-Bisnis. E-bisnis tidak hanya menyangkut ecommerce saja. Dalam hal ini e-commerce lebih merupakan sub bagian dari e-bisnis, sementara e-bisnis meliputi segala macam fungsi dan kegiatan bisnis menggunakan data elektronik termasuk emarket. E-business memiliki karakteristik tujuan yang sama dengan bisnis secara konvensional, hanya saja ebusiness memiliki cakupan yang berbeda. Bisnis mengandalkan pertemuan antar pebisnis seperti halnya rapat ditempat khusus, atau sekadar untuk berkenalan dengan partner bisnis, sedangkan ebusiness mengandalkan media internet sebagai sarana untuk memperoleh tujuannya. 
Sasaran dari e-business adalah pasar atau market. Menurut Forrester Research, telah terjadi perkembangan yang sangat fantastis terhadap jumlah komputer yang terhubung dalam internet, termasuk penggunanya. Ebusiness market ini menyimpan peluang omset yang besar yang dapat diperebutkan oleh para pebisnis. Bisnis online merupakan segala jenis kegiatan bisnis yang dilakukan secara online (melalui internet). Setiap pelaku usaha yang sebagian aktivitasnya ataupun semua aktivitas bisnisnya dilakukan melalui internet, bisa dikatakan mereka menjalankan bisnis online. Aktivitas bisnis online ini bisa meliputi kegiatan jual beli online, maupun menyediakan jasa secara online, dan banyak jenis bisnis lainnya yang bisa kita temukan di online di berbagai bidang industri. Intinya, jika Anda memiliki suatu ide bisnis maupun produk yang unik, Anda bisa langsung memulai menjualnya lewat internet. Artinya, semua orang bisa saja memulai bisnis online.

\section{B. PEMBAHASAN / STUDI KASUS}

Bisnis online adalah kegiatan bisnis yang dilakukan di dunia maya dengan bantuan internet. Menjalankan bisnis online memerlukan media online sebagai wahana berbisnis. Media online seperti website, blog, jejaring sosial maupun toko online dapat dijadikan penggerak bisnis. Aktivitas pemesanan, transaksi, pembayaran, konfirmasi, konsultasi semua kini dapat dilakukan secara mudah dengan online. Bisnis online memiliki prinsip yang sama dengan bisnis offline. Karena tetap harus ada barang maupun jasa yang nanti akan diperjual belikan, hanya saja dalam bisnis online berbagai kegiatan konvensional mulai digantikan dengan media online, seperti dalam hal pemasaran dan promosi . Kegiatan bisnis online dan offline berjalan saling mendukung dalam upaya mencapai tujuan usaha. Bisnis online adalah bisnis yang dapat dijalankan oleh siapa saja yang memiliki niat dan semangat tinggi. Bisnis online adalah bisnis potensial yang dapat diaplikasikan pada setiap usaha. Kemudahan akses internet dan layanan media online gratis dapat dimanfaatkan oleh orang orang yang ingin memulai bisnis online. Tantangan dalam bisnis online antara lain potensi berbisnis online memang cukup menggiurkan. Untuk mencapai kesusksesan dalam bisnis online tentu diperlukan niat sungguh - sungguh dan usaha. Apalagi jika anda adalah seseorang yang baru mengenal dunia internet atau orang yang baru mencoba mulai berbisnis. Siapkan mental anda dalam persaingan dunia global. Diawal perjalanan bisnis online 
akan jadi cukup sulit karena diperlukan proses memperkenalkan dan membangun reputasi di dunia global. Seiring berjalan waktu dan meningkatnya kualitas bisnis anda maka tujuan bisnispun niscaya akan dicapai. Perihal pengetahuan dan pengalaman juga menjadi faktor penting dalam menjalankan bisnis online. Kemampuan teknis dan ketrampilan khusus dalam internet juga diperlukan. Baca juga Hal Penting yang Harus Anda Ketahui Sebelum Memulai Bisnis Online. Dalam menjalankan bisnis online anda tidak bisa lepas dari kegiatan pemasaran. Temukan tips pemasaran era digital untuk meningkatkan profit usaha. Tantangan lain dalam bisnis online adalah penipuan. Bisnis online tidak bisa lepas dari kecurigaan terhadap praktek penipuan. Di Indonesia tidak sedikit laporan atas penipuan bisnis online bermunculan semenjak metode ini trend dilakoni oleh masyarakat. Berkembangnya teknologi telah membuat dunia pemasaran juga semakin berkembang. Sebagai bagian dari aktivitas bisnis ecommerce, jual-beli online pun semakin marak dilakukan. Tak usah keluar rumah dan menghadapi macetnya jalan jika ingin membeli suatu barang. Dengan bermodalkan Internet dan gadget, transaksi jual/beli menjadi sangatlah mudah. E-Commerce adalah aktivitas penyebaran, penjualan, pembelian, pemasaran produk (barang dan jasa), dengan memanfaatkan jaringan telekomunikasi seperti internet dan jaringan komputer. Arti E-commerce (Electronic Commerce) dapat juga didefinisikan sebagai aktivitas penggunaan teknologi informasi dan komunikasi pengolahan digital dalam melakukan transaksi bisnis untuk menciptakan, mengubah, dan mendefenisikan kembali hubungan antara penjual dan pembeli. Secara sederhana pengertian E-commerce dapat diartikan sebagai aktivitas transaksi jual-beli barang, servis atau transmisi dana atau data dengan menggunakan elektronik yang terhubung dengan internet. Transaksi ecommerce ini bukan lagi hal baru di tanah air, bahkan perkembangannya terbilang sangat pesat. Jenis-jenis ECommerce antara lain : 1. ECommerce Business to Business (B2B) yaitu Transaksi e-commerce ini dilakukan oleh dua belah pihak yang samasama memiliki kepentingan bisnis. Dua belah pihak ini saling mengerti dan mengetahui bisnis yang dijalankan. 2. E-commerce Business to Consumer (B2C) yaitu Business to consumer dilakukan oleh pelaku bisnis dan konsumen. Transaksi ecommerce ini terjadi layaknya jual-beli biasa. Konsumen 
mendapatkan penawaran produk dan melakukan pembelian secara online. 3. Ecommerce C2C (Konsumen $\mathrm{Ke}$ Konsumen) yaitu Untuk C2C, traksaksi dilakukan oleh konsumen ke konsumen. Kalau Anda sering menggunakan Tokopedia, Bukalapak, OLX dan sejenisnya, maka inilah yang dinamakan B2C ecommerce. 4. Consumen to Busines (C2B) yaitu C2B adalah kebalikan B2C yang mana konsumen terakhir bertindak sebagai penjual dan perusahaan bertindak sebagai pembeli. 5. Media atau Aplikasi E-commerce yaitu Seperti yang dijelaskan dalam pengertian e-commerce diatas, transaksi bisnis ini bergantung pada sejumlah aplikasi dan media online (baca: pengertian media online) lainnya, misalnya katalog, email, shopping carts, eb service, EDI dan file transfer protocol. Hal ini tentunya melibatkan kegiatan B2B (business to business). Mobile Bisnis atau M-Bisnis dapat diartikan sebagai bagian dari eBusiness di mana informasi tersedia independen waktu dan lokasi dimanapun kita berada. mbisnis sebagai aplikasi yang di butuhkan untuk mengelola segala sesuatu yang berhubungan dengan bisnis, penyajian informasi, jasa, dan komoditi-komoditi dengan menggunakan peralatan mobile. Perbedaan ECommerce dan E-Bisnis, pada dasarnya, e-commerce dan juga e-business bisa kita bedakan dengan sangat mudah. Hampir semua e-commerce adalah bagian dari e-business, jadi tidak salah apabila kita menyebutkan banyak toko toko online sebagai bentuk dari e-commerce ataupun ebusiness. Namun demikian, tetap ada sebuah perbedaan antara kedua layanan yang berada di dalam jaringna internet ini, yaitu: 1.E-business mencakup area yang sangat luas, mulai dari pembangunan modal, sumber daya manusia, sumber daya teknologi, proses marketing dan pemasaran, manajemen perkantoran, proses audit, dan segala macam elemen lainnya. Sedangkan, ecommerce hanya berfokus pada proses jual beli atau pemindahtanganan yang dilakukan melalui proses transaksi secara elektronik di sebuah situs. 2. E-commerce merupakan bagian kecil dari sebuah e-business. Ibaratnya, apabila kita ibaratkan sebagai tubuh manusia, e-business adalah seluruh tubuh manusia, sedangkan e-commerce hanyalah bagian tangan kiri atau tangan kanan manusia saja. 3. E-commerce hanya membutuhkan spesifikasi dan jga kemampuan analisa dari segi penjualan dan transaksi saja. Sedangkan e-business membutuhkan pertimbanan matang dari berbagai aspek, mulai dari aspek pemasaran, produksi, dan sebagainya. 
C. ID SECURITY

QWTD4452377-ASP-5244107

\section{KESIMPULAN}

Kesimpulan dari materi ini adalah diakui atau tidak, perkembangan e-commerce sekarang sudah jauh melampau ekspektasi dan membentuk selera konsumen dalam berbelanja. kecepatan akses, stok yang lebih banyak pilihan, hemat waktu dan uang menjadikan hal ini kebutuhan utama. Hanya saja ada sedikit gangguan dengan minimnya customer service yang tidak bisa bersentuhan langsung dengan produk real (untuk produk tertentu). Juga, kekurangan e-commerce akan selalu terkendala dengan jangka waktu pengiriman barang. Saat ini, E-commerce adalah bidang yang paling empuk untuk digeluti. Perubahan konsumen dalam negeri sudah semakin mengeliat dilihat dari kegemaran belanja online dan juga lahirnya startup di berbagai bidang. Electronic Business atau E-Business adalah suatu kegiatan transaksi, jual-beli, bisnis yang dilakukan melalui perangkat elektronik atau dengan internet sehingga perusahaan dapat langsung berinteraksi dengan costumer, supplier maupun rekan bisnis. Atau arti yang lebih singkat dari e-business yaitu penggunaan Teknologi Informasi dan Komunikasi untuk menjalankan sekaligus mengelola bisnisnya sehingga dapat memperoleh keuntungan. Teknologi Informasi dan Komunikasi pada e-business digunakan untuk meningkatkan bisnis perusahaan yang mencangkup semua aspek yang berorientasi pada profit maupun nonprofit suatu perusahaan. Dibalik semua tantangan dalam bisnis online, ada manfaat besar bisa kita dapatkan, diantarnya; pertama, kemudahan akses, karena masuk dalam jaringan global, setiap orang bisa mengakses bisnis kita tanpa batas waktu. Bisnis kita bisa buka 24 jam. Kedua, lebih hemat karena tidak ada sewa toko ataupun anggaran gaji untuk staff penjaga toko. Ketiga, Produk flexibel dan bisa berbagai jenis barang, ini bisa dilakukan dengan bisnis online model afiliansi.

\section{E. DISKUSI}

Saya telah berdiskusi bersama teman saya bernama Imam Saputra mendiskusikan tentang E-Commerce, E-Bisnis dan MBisnis menuut dia pengertian E-Commerce adalah aktivitas penyebaran, penjualan, pembelian, pemasaran produk (barang dan jasa), dengan memanfaatkan jaringan telekomunikasi seperti internet dan jaringan komputer. Secara sederhana pengertian Ecommerce dapat diartikan sebagai aktivitas transaksi jualbeli barang, servis atau 


transmisi dana atau data
dengan menggunakan
elektronik yang terhubung
dengan internet. Transaksi e-
commerce ini bukan lagi hal
baru di tanah air, bahkan
perkembangannya terbilang
sangat pesat. Sedangkan E-
Bisnis adalah kegiatan bisnis
yang dilakukan secara otomatis
dengan memanfaatkan
teknologi elektronik seperti
komputer dan internet.
Kegiatan E-business juga
memungkinkan suatu
perusahaan untuk berhubungan
dengan sistem pemrosesan data
internal dan eksternal secara
lebih efisien dan fleksibel.
Menurut dia E-Commerce
bagian dari E-Bisnis karena E-
bisnis tidak hanya menyangkut
tentang jual beli saja tetapi
seluruh kgiatan bisnis yang
ada. Dan M-Bisnis atau Mobile
Bisnis menurutnya adalah
suatu transaksi bisnis bergerak.
m-Bisnis hampir sama dengan
m-Commerce yakni transaksi
yang dilakukan dimana saja
dengan menggunakan alat
portabel lewat jaringan
nirkabel.

\section{F. REFERENCE}


[1] O. M. Febriani and A. S. Putra, "Sistem Informasi Monitoring Inventori Barang Pada Balai Riset Standardisasi Industri Bandar Lampung," J. Inform., vol. 13, no. 1, pp. 90-98, 2014.

[2] A. S. Putra, "Paperplain: Execution Fundamental Create Application With Borland Delphi 7.0 University Of Mitra Indonesia," 2018.

[3] A. S. Putra, "2018 Artikel Struktur Data, Audit Dan Jaringan Komputer," 2018.

[4] A. S. Putra, "ALIAS MANAGER USED IN DATABASE DESKTOP STUDI CASE DB DEMOS."

[5] A. S. Putra, "COMPREHENSIVE SET OF PROFESSIONAL FOR DISTRIBUTE COMPUTING."

[6] A. S. Putra, "DATA ORIENTED RECOGNITION IN BORLAND DELPHI 7.0."

[7] A. S. Putra, "EMBARCADERO DELPHI XE 2 IN GPUPOWERED FIREMONKEY APPLICATION."

[8] A. S. Putra, "HAK ATAS KEKAYAAN INTELEKTUAL DALAM DUNIA TEKNOLOGY BERBASIS REVOLUSI INDUSTRI 4.0."

[9] A. S. Putra, "IMPLEMENTASI PERATURAN PERUNDANGAN UU. NO 31 TAHUN 2000 TENTANG DESAIN INDUSTRI BERBASIS INFORMATION TECHNOLOGY."

[10] A. S. Putra, "IMPLEMENTATION OF PARADOX DBASE."
[11] A

S. Putra, "IMPLEMENTATION OF TRADE SECRET CASE STUDY SAMSUNG MOBILE PHONE."

[12] A. S. Putra, "IMPLEMENTATION PATENT FOR APPLICATION WEB BASED CASE STUDI WWW. PUBLIKLAMPUNG. COM."

A. S. Putra, "IMPLEMENTATION SYSTEM FIRST TO INVENT IN DIGITALLY INDUSTRY."

[14] A. S. Putra, "MANUAL REPORT \& INTEGRATED DEVELOPMENT

ENVIRONMENT BORLAND DELPHI 7.0."

[15] A. S. Putra, "PATENT AS RELEVAN SUPPORT RESEARCH."

[16] A. S. Putra, "PATENT FOR RESEARCH STUDY CASE OF APPLE. Inc."

[17] A. S. Putra, "PATENT PROTECTION FOR APPLICATION INVENT."

[18] A. S. Putra, "QUICK REPORT IN PROPERTY PROGRAMMING."

[19] A. S. Putra, "REVIEW CIRCUIT LAYOUT COMPONENT

REQUIREMENT ON ASUS NOTEBOOK."

[20] A. S. Putra, "REVIEW TRADEMARK PATENT FOR INDUSTRIAL TECHNOLOGY BASED 4.0."

[21] A. S. Putra, "TOOLBAR COMPONENT PALLETTE IN OBJECT ORIENTED PROGRAMMING." 
[22] A. S. Putra, "WORKING DIRECTORY SET FOR PARADOX 7."

[23] A. S. Putra, "ZQUERY CONNECTION IMPLEMENTED PROGRAMMING STUDI CASE PT. BANK BCA Tbk."

[24] A. S. Putra, D. R. Aryanti, and I. Hartati, "Metode SAW (Simple Additive Weighting) sebagai Sistem Pendukung Keputusan Guru Berprestasi (Studi Kasus: SMK Global Surya)," in Prosiding Seminar Nasional Darmajaya, 2018, vol. 1, no. 1, pp. 85-97.

[25] A. S. Putra and O. M. Febriani, "Knowledge Management Online Application in PDAM Lampung Province," in Prosiding International conference on Information Technology and Business (ICITB), 2018, pp. 181-187.

[26] A. S. Putra, O. M. Febriani, and B. Bachry, "Implementasi Genetic Fuzzy System Untuk Mengidentifikasi Hasil Curian Kendaraan Bermotor Di Polda Lampung," SIMADA (Jurnal Sist. Inf. dan Manaj. Basis Data), vol. 1, no. 1, pp. 21-30, 2018.

[27] A. S. Putra, H. Sukri, and K. Zuhri, "Sistem Monitoring Realtime Jaringan Irigasi Desa (JIDES) Dengan Konsep Jaringan Sensor Nirkabel," IJEIS (Indonesian J. Electron. Instrum. Syst., vol. 8, no. 2, pp. 221-232.

[28] D. P. Sari, O. M. Febriani, and A. S. Putra, "Perancangan Sistem Informasi SDM
Berprestasi pada SD Global Surya," in Prosiding Seminar Nasional Darmajaya, 2018, vol. 1, no. 1, pp. 289-294. 